\title{
Salmonella Typhimurium environmental reduction in a farrow-to-finish pig herd using a live attenuated Salmonella Typhimurium vaccine
}

Peter van der Wolf ${ }^{* *}$, Maaike Meijerink', Emile Libbrecht ${ }^{2}$, Gerrit Tacken $^{3}$, Emile Gijsen³ Kathrin Lillie-Jaschniski ${ }^{4}$ and Verena Schüller ${ }^{4}$

\begin{abstract}
Background: Salmonella Typhimurium is an important zoonotic pathogen in pigs, that can cause clinical disease. Many sow herds and finishing herds are infected with Salmonella, and therefore pose a threat for the contamination of pork and pork products and ultimately consumers.

Case presentation: This case study describes a farrow-to-finish pig herd, producing its own replacement gilts, which had experienced clinical outbreaks of salmonellosis since 2002. Outbreaks were characterised by profuse diarrhoea, dead pigs and high antimicrobial use (colistin sulphate). The aim of this study was to see whether using vaccination of sows and piglets with Salmoporc ${ }^{\oplus}$, a live attenuated Salmonella Typhimurium vaccine, in combination with standard hygienic precautions, it was possible to reduce Salmonella Typhimurium to below the bacteriological detection limit. Monitoring of the presence of Salmonella was done using a total of 20 pooled faecal, sock and dust samples per herd visit in the period from September 2016 to October 2020. Within the first 10 months after the start of vaccination in August 2016, there was a rapid reduction in clinical symptoms, antimicrobial usage and the number of Salmonella-positive samples. During the winters of 2017/2018 and 2018/2019 the number of positive samples increased again, however with minimal need to use antimicrobials to treat the affected animals. In July 2019, only two samples from a corridor were positive. In September and November 2019 and in October 2020 all three samplings were completely negative for S. Typhimurium.
\end{abstract}

Conclusions: This case, together with other longitudinal studies, can be seen as a proof of the principle that long term vaccination with a live attenuated $S$. Typhimurium vaccine can reduce the level of $S$. Typhimurium in the herd environment to very low levels within a farrow-to-finish herd initially suffering from clinical salmonellosis. Also, clinical symptoms indicating salmonellosis were no longer observed and antimicrobials to treat clinically diseased pigs were no longer needed.

Keywords: Salmonella, Swine, Pig, Vaccination, Eradication, Disease control, Risk factors, Salmonellosis, Zoonosis, Antimicrobial use

\footnotetext{
* Correspondence: peter.van-der-wolf@ceva.com

${ }^{1}$ Ceva Santé Animale BV, Naaldwijk, The Netherlands

Full list of author information is available at the end of the article
}

(c) The Author(s). 2021 Open Access This article is licensed under a Creative Commons Attribution 4.0 International License, which permits use, sharing, adaptation, distribution and reproduction in any medium or format, as long as you give appropriate credit to the original author(s) and the source, provide a link to the Creative Commons licence, and indicate if changes were made. The images or other third party material in this article are included in the article's Creative Commons licence, unless indicated otherwise in a credit line to the material. If material is not included in the article's Creative Commons licence and your intended use is not permitted by statutory regulation or exceeds the permitted use, you will need to obtain permission directly from the copyright holder. To view a copy of this licence, visit http://creativecommons.org/licenses/by/4.0/ The Creative Commons Public Domain Dedication waiver (http://creativecommons.org/publicdomain/zero/1.0/) applies to the data made available in this article, unless otherwise stated in a credit line to the data. 


\section{Background}

Salmonella and particularly Salmonella Typhimurium (S. Typhimurium or ST) is an important zoonotic pathogen occurring worldwide [1-3], able to cause serious extra-intestinal disease in humans [4]. Salmonella Typhimurium, and it's monophasic variant, is a pathogen in the pig industry that can infect and colonize pigs [5]. This can lead to enteritis, both acute and subclinical, accompanied by a reduction in average daily weight gain and an increase in feed conversion ratio. In some cases (per)acute mortality, mainly in growers and finishers, can occur in any age category [6-8]. Control of Salmonella is difficult and based on the control of many different risk factors within pig herds [9]. Relevant control factors include all-in/all-out procedures, internal and external biosecurity, rodent-, fly- and beetle control, thorough cleaning and disinfection, improved pig management practices (e.g. reduction of cross fostering of suckling piglets and mixing of piglets at weaning or at transfer to the grow/finishing units), the use of specialized feed formulations, the use of organic acids and vaccination and the control of concomitant infections like Ascaris suum, PRRSV, ileitis or dysentery [10-17].

Abundance of Salmonella in the environment and within pig farms makes a lasting Salmonella free status of pig farms a difficult goal. However, pig farms in Norway and Sweden are practically free of Salmonella $(<0.1 \%$ prevalence at herd level $[18,19])$ and pig farms that use fermented liquid feed as a feeding system [20, 21] can remain free of Salmonella for at least 2 years [22] in a country with a high prevalence of Salmonella in sow herds [23]. For the control of Salmonella Typhimurium in pig herds, in addition to trying to control all possible risk factors, an option is to use vaccination as a tool to boost immunity in the pigs and consequently reduce both their susceptibility to infection and shedding after infection. Salmoporc ${ }^{\circ}$ (Ceva Santé Animale, Libourne, France, formerly IDT Biologika GmbH, Dessau, Germany) is a lyophilizate of a genetically stable live double attenuated (histidine-adenine-auxotrophe) Salmonella Typhimurium strain (nr. 421/125). After dilution, one dose of $1 \mathrm{ml}$ contains $5^{*} 10^{\wedge} 8$ to $5^{*} 10^{\wedge} 9$ colony forming units. In sows it is applied by subcutaneous injection, in piglets it is given twice orally by drench. Salmoporc $^{\circ}$ is registered in several European countries, including Belgium and The Netherlands. The claims of the vaccine are that in gilts and sows it will induce immunity and reduce shedding during lactation and in piglets it will induce active immunity resulting in a reduction in colonisation, shedding and clinical symptoms. As the vaccine is a live vaccine, even sub cutaneous instead of oral administration stimulates both humoral and cellular immunity and therefore able to protect against an enteric pathogen and reduce its shedding [24]. High humoral and cellular immunity in piglets is desirable to protect against early colonisation of newborn piglets, even though piglets are vaccinated from 4 days of live. Maternally derived immunity does not interfere with the effect of the vaccination of piglets, on the contrary, Rösler et al. showed that vaccinated piglets from vaccinated sows had significantly lower infection levels after challenge than vaccinated piglets from unvaccinated sows [25]. The effectiveness of Salmoporc ${ }^{\circ}$ is well documented [26-29] for the reduction of colonisation and shedding of Salmonella Typhimurium, sometimes even in the unvaccinated progeny of vaccinated sows [30, 31]. However, to our knowledge, no studies exist that followed a vaccinated herd to the point where Salmonella Typhimurium could no longer be isolated from faecal and dust samples.

The aim of this study was, next to the reduction of clinical salmonellosis and antimicrobial use, to investigate whether it was possible to reduce Salmonella Typhimurium in a farrow-to-finish pig herd with a history of clinical salmonellosis to below the bacteriological detection limit, using vaccination of sows and piglets with Salmoporc ${ }^{\circ}$.

\section{Material and methods}

\section{The farm}

The herd in this study is located in the north-eastern part of Belgium close to the Dutch border. The herd is a 260-sow multiplying herd, producing its own replacement gilts and finishing pigs. Sperm doses are brought in from a boar stud outside the farm. The herd is managed based on a five-week production cycle. The herd consists of 4 buildings (barns A - D, Fig. 1).

Replacement gilts (approx. 50-60) and grow/finishing pigs are mostly housed in separate compartments within the same barns (Fig. 1, C and D). Additionally, some of the growers (approx. $25 \mathrm{~kg} \mathrm{BW)} \mathrm{are} \mathrm{moved} \mathrm{to} \mathrm{an} \mathrm{off-site}$ finishing unit or are sold to other local farms (not included in this study). The herd is entered via a changing room located at the entrance of the sow barn (Fig. 1, $\mathrm{Ch}$ ), where boots and overalls are supplied to visitors and there are hand washing facilities. There is no strict separation between clean and dirty areas, transport lorries for feed, slurry and farm supplies and visitors use the farmyard between the sow barn and the other barns (Fig. 1, farm yard). Boots are not changed and boot dips are not used between barns. To reach the barns of the gilts and the finishers (Fig. 1, C and D), one has to walk along the central corridor of the barn housing the weaned piglets (Fig. 1, C2). Compartments are managed on an all-in/all-out basis. Empty compartments are cleaned by high pressure cleaner with cold water and sanitised with a disinfectant containing glutaraldehyde/ quaternary ammonium components according to the 


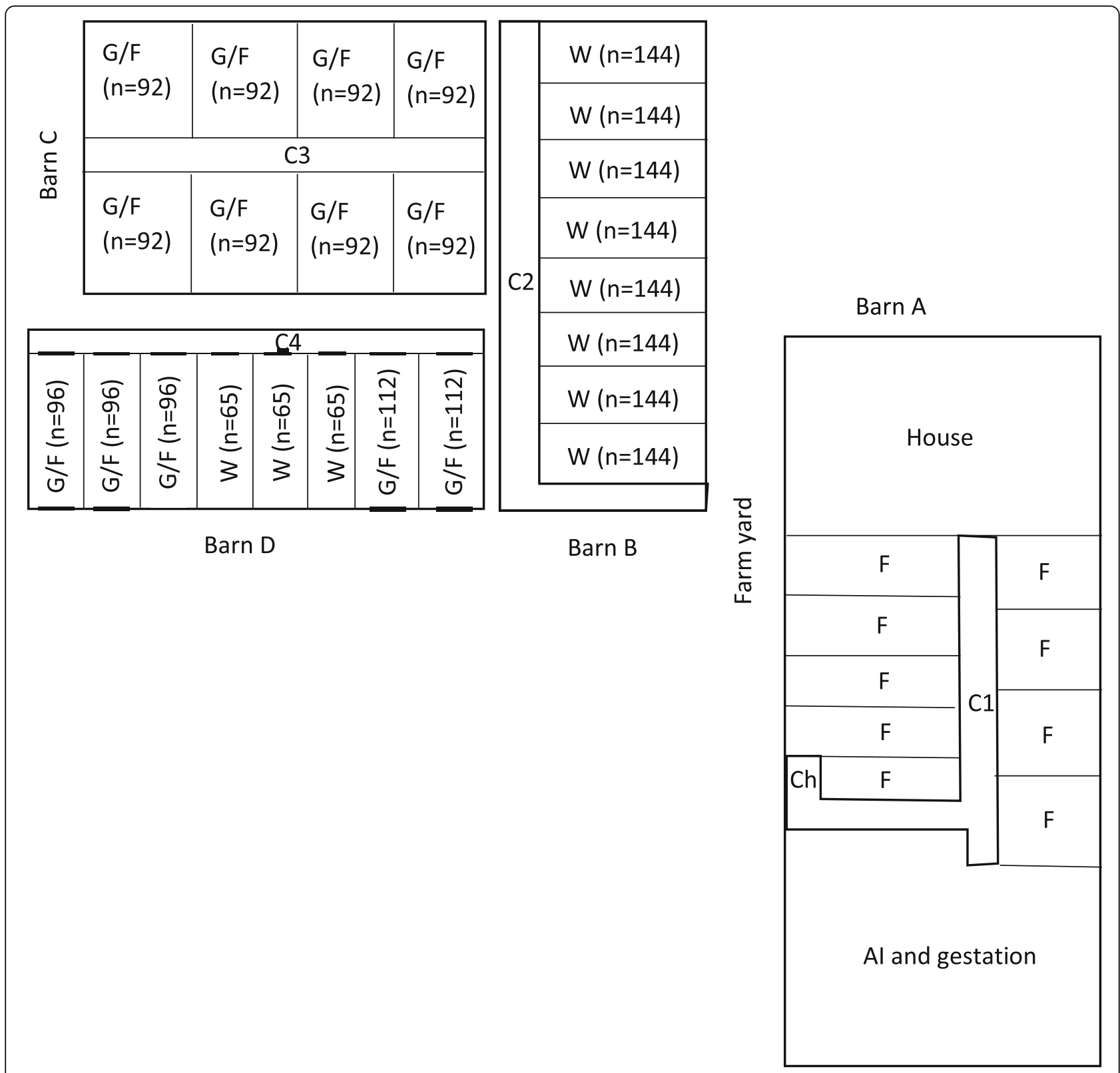

Fig. 1 Layout of the trial farm. Ch: Changing room, C1 - C4: corridors, F: Farrowing, W: Weaned piglets, G/F: Grow/Finishers, number of animals per compartment given in brackets

manufacturer's instructions (Megades $\mathrm{Novo}^{\circ}$, Schippers, The Netherlands). The floors in gestation, AI-centre and the compartments with weaned piglets are fully slatted. Floors in the finishing barns are made of concrete and partly slatted within each pen. Pen separations do not prevent exchange of faeces and/or urine between pens. Flies and mice are present, but not in large numbers. Rodent and fly control is done by the farmer himself. All pigs are fed compound pelleted feed suitable for their age group or production cycle. No routine preventive antimicrobials were used in this farm, however quite a lot of antimicrobials were used especially in weaned piglets for the (metaphylactic) treatment of infections caused by Streptococcus suis, $76.3 \%$ of all antimicrobials used in the years 2014-2020. In Table 1 the total added antimicrobial treatment index values as defined by AMCRA in Belgium (BD100, www.amcra.be/nl/analyseantibioticagebruik/) is given for the years 2014-2020, per pig category treated and per antimicrobial category. Polymyxins, specifically used to treat clinical salmonellosis in this farm, were never used in sows or suckling piglets. Weaned piglets and grow/fattening pigs were treated with polymyxins orally via the drinking water. 
Table 1 Total added antimicrobial treatment index values applicable in Belgium (BD100) per year, presented for the years 20142020, per pig category treated and per antimicrobial category. Colours: green: acceptable level of use, yellow: attention level, red: action level (AMCRA, Belgium)

\begin{tabular}{l|rrrrrrr|rr}
\hline & & & & & & & \multicolumn{3}{c}{$\%$ of } \\
\hline Pig category \Year & 2014 & 2015 & 2016 & 2017 & 2018 & 2019 & 2020 & Total & \multicolumn{2}{c}{ Total } \\
\hline Suckling piglets & $\mathbf{1 8 9 . 6}$ & $\mathbf{0}$ & $\mathbf{0}$ & $\mathbf{0}$ & $\mathbf{0}$ & $\mathbf{0}$ & $\mathbf{0}$ & $\mathbf{1 8 9 . 6 0}$ & $\mathbf{4 . 2 \%}$ \\
Macrolides & 103.4 & & & & & & & $\mathbf{1 0 3 . 4 0}$ & $2.3 \%$ \\
Penicillins & 86.2 & & & & & & & $\mathbf{8 6 . 2 0}$ & $1.9 \%$ \\
\hline Weaned piglets & $\mathbf{5 8 3 . 9}$ & $\mathbf{5 9 4 . 5}$ & $\mathbf{9 6 7 . 7 5}$ & $\mathbf{8 9 7 . 5 5}$ & $\mathbf{4 2 0 . 5 4}$ & $\mathbf{5 0 7 . 2 5}$ & $\mathbf{3 6 . 8 5}$ & $\mathbf{4 0 0 8 . 3 4}$ & $\mathbf{8 8 . 6 \%}$ \\
Macrolides & 0.5 & 5.3 & 5.81 & 5.6 & & 13.53 & & $\mathbf{3 0 . 7 4}$ & $0.7 \%$ \\
Penicillins & 445.1 & 424.7 & 806.44 & 891.95 & 420.54 & 426.5 & 36.85 & $\mathbf{3 4 5 2 . 0 8}$ & $76.3 \%$ \\
Polymyxins & & 106.2 & 155.5 & & & 8.77 & & $\mathbf{2 7 0 . 4 7}$ & $6.0 \%$ \\
Tetracyclines & 138.3 & 58.3 & & & & 58.45 & & $\mathbf{2 5 5 . 0 5}$ & $5.6 \%$ \\
\hline Grow / Fatteners & $\mathbf{5 7 . 9}$ & $\mathbf{3 7 . 6}$ & $\mathbf{2 2 . 7 4}$ & $\mathbf{2 9 . 5 4}$ & $\mathbf{3 1 . 4 5}$ & $\mathbf{1 7 . 9 8}$ & $\mathbf{5 2 . 7 9}$ & $\mathbf{2 5 0 . 0 0}$ & $\mathbf{5 . 5 \%}$ \\
Aminoglycosides & & & & 0.76 & 0.23 & 1.62 & 1.16 & $\mathbf{3 . 7 7}$ & $0.1 \%$ \\
Macrolides & 9.8 & 31 & 22.66 & & & 11.74 & 8.55 & $\mathbf{8 3 . 7 5}$ & $1.9 \%$ \\
Penicillins & 4.9 & & & & 21.53 & & 43.08 & $\mathbf{6 9 . 5 1}$ & $1.5 \%$ \\
Polymyxins & 43.2 & 6.6 & & 13.66 & 2.77 & & & $\mathbf{6 6 . 2 3}$ & $1.5 \%$ \\
Tetracyclines & & & 0.08 & 15.12 & 6.92 & 4.62 & & $\mathbf{2 6 . 7 4}$ & $0.6 \%$ \\
\hline Breeding pigs & $\mathbf{1 . 3}$ & $\mathbf{8 . 6}$ & $\mathbf{7 . 5 8}$ & $\mathbf{4 . 1 5}$ & $\mathbf{2 . 1 9}$ & $\mathbf{0 . 6 5}$ & $\mathbf{4 9 . 3 8}$ & $\mathbf{7 3 . 8 5}$ & $\mathbf{1 . 6 \%}$ \\
Macrolides & & 7.7 & 4.88 & & & & 0.9 & $\mathbf{1 3 . 4 8}$ & $0.3 \%$ \\
Penicillins & & & 1.82 & 1.43 & 1.34 & 0.12 & 43.89 & $\mathbf{4 8 . 6 0}$ & $1.1 \%$ \\
Tetracyclines & 1.3 & 0.9 & 0.88 & 2.72 & 0.85 & 0.53 & 4.59 & $\mathbf{1 1 . 7 7}$ & $0.3 \%$ \\
\hline Total & $\mathbf{8 3 2 . 7}$ & $\mathbf{6 4 0 . 7}$ & $\mathbf{9 9 8 . 0 7}$ & $\mathbf{9 3 1 . 2 4}$ & $\mathbf{4 5 4 . 1 8}$ & $\mathbf{5 2 5 . 8 8}$ & $\mathbf{1 3 9 . 0 2}$ & $\mathbf{4 5 2 1 . 7 9}$ & $\mathbf{1 0 0 \%}$ \\
\hline
\end{tabular}

Salmonella history of the farm

A chronological history of the development of the Salmonella situation on the herd is given in Table 2 in the period from 2002 to August 2016 when vaccination was started.

\section{Other vaccinations}

In general, the sows are mass vaccinated against PRRSV four times per year; E. coli at the end of gestation; and Parvo / Erysipelas during lactation. The replacement gilts are vaccinated against Mycoplasma hyopneumoniae at 17 days of age; ileitis (Lawsonia intracellularis) at 20 days of age; PRRSV together with the sows and Parvo / Erysipelas during the rearing period from 3 to 7 months of age. An outbreak of PRRSV occurred in the sows in 2018, which lasted for approx. 6 months.

\section{Choice of diagnostic method}

Several methods can be used to assess the Salmonella status of pigs and pig farms. Serology based on ELISAs [32] can be used on a herd level or national level or even in small studies to assess the effect of Salmonella interventions [29, 33], but ELISAs cannot differentiate between antibodies in response to infection with field strains or vaccination with Salmoporc [34], making this method unsuitable for our study. Another option would be to look at mesenteric lymph nodes at the slaughterhouse, however, cross contamination during the period of transport, holding and slaughter cannot be ruled out and would make genetic differentiation of field strains necessary to make sure that the collected field strains originated from this farm, which is labour intensive, costly and already done before [35]. Therefore we chose for collecting faecal and dust samples from the pens and corridors in the farm itself, also because a reduction of shedding are claims of the vaccine for both sows and piglets.

\section{Sampling procedure of pooled faecal samples, sock samples, dust samples}

Pooled faecal samples were collected in $50 \mathrm{ml}$ plastic containers. From every pen within a compartment at least two faecal samples, taken from the floor of the pens, were added to the pool. One pooled sample represented one compartment. The plastic containers were labelled with an identification number corresponding to the sampling protocol. Sock samples were collected by covering each boot with a plastic overshoe (boot cover, 
Table 2 Chronological history of the Salmonella situation at the farm. Presented are the date, the subject and the source of the information in the period from 2002 to 2016

\begin{tabular}{|c|c|c|}
\hline November 2002 & $\begin{array}{l}\text { The earliest mention of diarrhoea, describing considerable amounts of grey, } \\
\text { yellow and sometimes black diarrhoea }\end{array}$ & Visit report of the veterinarian \\
\hline September 2004 & $\begin{array}{l}\text { Confirmation of anti-Lawsonia intracellularis serum lgG in pigs over } 50 \mathrm{~kg} \text { of } \\
\text { body weight and advises medication with Tylosin }\end{array}$ & Visit report of the veterinarian \\
\hline April 2005 & $\begin{array}{l}\text { Confirmation of Salmonella in faecal samples of gilts of } 40-60 \mathrm{~kg} \text { of body } \\
\text { weight and advised treatment with Enrofloxacin (Baytril }{ }^{\oplus} \text { ) and colistin sulphate. } \\
\text { The appearance of runts in pigs over } 30 \mathrm{~kg} \text { of body weight is mentioned as a problem. }\end{array}$ & Visit report of the veterinarian \\
\hline \multirow[t]{2}{*}{ October 2009} & $\begin{array}{l}\text { High S/P-ratio values in the Salmonella ELISA, especially in heavy finishers } \\
>80 \mathrm{~kg} \text { BW ( } 4 \text { out of } 7 \text { pigs sampled had S/P-ratio values }>2 \text {, all } 7 \text { pigs were } \\
\text { positive at cut-off } 0.6 \text { ) }\end{array}$ & Laboratory DGZ Vlaanderen vzu \\
\hline & $\begin{array}{l}\text { Later reports mention different S/P-ratio values, sometimes high, sometimes low, } \\
\text { in pigs of } 40 \mathrm{~kg} \text { body weight and upwards }\end{array}$ & Laboratory DGZ Vlaanderen vzu \\
\hline $2012-2015$ & All most all reports mention Salmonella as a problem & Visit reports of the veterinarian \\
\hline October 2012 & $\begin{array}{l}\text { The Salmonella expert from the Animal Health Service Flanders visited the herd } \\
\text { to provide advice. Different acids (based on formic acid or coated butyrate) were } \\
\text { tried through feed and/or drinking water, however concentrations nor duration of } \\
\text { treatment nor pig category were specified or recorded. }\end{array}$ & DGZ Vlaanderen vzW \\
\hline October 2012 & $\begin{array}{l}\text { A faecal sample from sows and gilts / finishers tested positive for Salmonella } \\
\text { Typhimurium O5+ which was sensitive to all tested antimicrobials including colistin. }\end{array}$ & $\begin{array}{l}\text { DGZ Vlaanderen vzw, typing by } \\
\text { CODA-CERVA }\end{array}$ \\
\hline March 2013 & $\begin{array}{l}\text { Two heavy finishers ( } 104 \text { and } 106 \mathrm{~kg} \text { body weight respectively) were submitted } \\
\text { for post-mortem examination and enteritis caused by Salmonella Typhimurium } \\
\text { O5+ was confirmed }\end{array}$ & $\begin{array}{l}\text { DGZ Vlaanderen vzw, typing by } \\
\text { CODA-CERVA }\end{array}$ \\
\hline October 2013 & $\begin{array}{l}\text { Seven pigs died of which } 4 \text { were presumed to have died of salmonellosis. } \\
\text { Colistin sulphate is used regularly to treat for diarrhoea. }\end{array}$ & Visit report of the veterinarian \\
\hline April 2014 & $\begin{array}{l}\text { The report mentions the options of vaccinating for Salmonella and the use of } \\
\text { butyric acid in the feed. }\end{array}$ & Visit report of the veterinarian \\
\hline 2014-2016 & $\begin{array}{l}\text { As soon as diarrhoea appeared, antimicrobials containing colistin sulphate } \\
\text { (Colistine-mix } 1.2 \text { milj. I.U./g, } 1 \mathrm{~kg} \text { during } 2015, \text { dose } 5 \mathrm{mg} / \mathrm{kg} \text { BW via drinking } \\
\text { water for } 5-7 \text { days and Promycine Pulvis } 4800 \mathrm{IE} / \mathrm{mg}, 1 \mathrm{~kg} \text {, dose } 100,000 \mathrm{I.U} \text {. } \\
\text { per kg BW for 3-5 days via the drinking water after 2015) were used to treat } \\
\text { the pigs. }\end{array}$ & AMCRA Belgium \\
\hline May 2016 & $\begin{array}{l}\text { Salmonellosis was confirmed after typing of } 4 \text { isolates from diarrhoea samples } \\
\text { as Salmonella } \\
\text { Typhimurium O5+ which were sensitive to all tested antimicrobials including colistin. }\end{array}$ & $\begin{array}{l}\text { DGZ Vlaanderen vZw, typing by } \\
\text { CODA-CERVA }\end{array}$ \\
\hline October 2016 & $\begin{array}{l}\text { Necropsy of } 3 \text { non-vaccinated finishing pigs ( } 80,80 \text { and } 84 \mathrm{~kg} \text { body weight), } \\
\text { showing moderate congestion of the mesenteric lymph nodes, dilated jejunum } \\
\text { with yellow-brown fluid content including some Ascaris suum worms, very fluid } \\
\text { yellow-brown content of the large intestine, confirmed they died of salmonellosis } \\
\text { caused by S. Typhimurium O5+ which was sensitive to all tested antimicrobials } \\
\text { including colistin. }\end{array}$ & $\begin{array}{l}\text { DGZ Vlaanderen vZw, typing by } \\
\text { CODA-CERVA }\end{array}$ \\
\hline
\end{tabular}

transparent, Covetrus, The Netherlands) at the entrance of the compartment. A sock (non-skid, non-conductive, blue shoe covers, Henry Schein, Covetrus, The Netherlands) was put over one plastic overshoe to collect faecal material from the floor of all pens within the compartment. With this sock we purposefully stepped into faecal material accumulated in each pen, usually along the walls and in the corners of the pen. One sock was collected per compartment. When sampling corridors using these socks, also we purposefully stepped in any faecal material present. The socks were placed in individual plastic bags which were closed by tying a knot in the bag. Each bag was labelled with an identification number corresponding to the sampling protocol. Dust samples were collected wearing non-sterile gloves (lightly powdered latex examination gloves, Henry Schein, Covetrus, The Netherlands) and wiping as many surfaces as possible, both at animal level e.g. driving board, shovels, boots, walls, doors and higher, e.g. window sills, the top of pen separations and feeders, feed pipelines, ventilation shafts, in either a compartment or a corridor while collecting the sock and pooled faecal samples. For the dust wipes we used synthetic dust cloth (dry Swiffer ${ }^{\circ}$ wipes or comparable local wipes from Action shop), one wipe per compartment or corridor [36]. The dust wipes were handled like the socks. All samples were shipped cooled by overnight courier to the laboratory. All samplings were carried out by a trained experienced person employed by either IDT Animal Health or after July 1st, 2019 Ceva Santé Animale. 
Sampling scheme of pooled faecal samples, sock samples, dust samples

Samplings were done every 4 weeks from August 2016 till April 2018. Since then, samplings were done every 8 weeks till November 2019 and the last one in October 2020.

Three different sampling schemes (I, II, III) were used for collecting pooled faecal, sock and dust samples, due to an improvement of the sampling scheme during the study [36]. The first change was to stop collecting pooled faecal samples. Instead, a sock and a dust sample was collected from each compartment or corridor. The change from II to III was that in compartments with pigs, no more dust swabs were taken, but more compartments were sampled with socks per visit. Sampling Scheme II was implemented starting November 2016 and samplings Scheme III starting May 2017 until the end of the trial. The type and number of samples taken at each herd visit are listed in Table 3 in the results. Slight variations on these sampling schemes were sometimes necessary due to the circumstances at the time of sampling, for example if there were no piglets present in the farrowing compartments due to the five-week farrowing batch system.

\section{Bacteriological analysis}

Bacteriological analysis of the pooled faecal, sock and dust samples was performed by the Microbiological Institute of the Centre for Infectious Diseases of the Veterinary University of Hannover (Institut für Mikrobiologie, Zentrum für Infektionsmedizin, Stiftung TiHo Hannover), using a protocol that was validated in comparison with the ISO-standard 6579 1:2017 and was found to be more sensitive than the ISO-standard. Samples were inoculated into $225 \mathrm{ml}$ buffered peptone water (BPW; Oxoid, Germany) and incubated for $18 \mathrm{~h}$ at $37^{\circ} \mathrm{C}$. One $\mathrm{ml}$ of this non-selective pre-enrichment was transferred to $8 \mathrm{ml}$ tetrathionate brilliant green bile broth (TBG; VWR, Germany) and $0.1 \mathrm{ml}$ was transferred to Rappaport Vassiliadis Soy broth (RVS; Oxoid, Germany). The selective liquid media were incubated for $24 \mathrm{~h}$ at $42{ }^{\circ} \mathrm{C}$ and then streaked on Oxoid Brilliance Salmonella agar. After $24 \mathrm{~h}$ at $37^{\circ} \mathrm{C}$ plates were inspected for growth of typical purple colonies. Colonies were subcultured on non-selective Columbia sheep blood agar (Oxoid, Germany). Isolates were submitted to an in-house-PCR that can specifically identify Salmonella Typhimurium as well as non-specifically Salmonella enterica ssp. enterica and Salmonella genus based on Park et al. [37]. One isolate per sample was typed. Isolates only identified as Salmonella enterica ssp. enterica or Salmonella genus by PCR were further characterized by slide agglutination with $\mathrm{O}-$ and $\mathrm{H}$-specific antisera (Sifin, Germany, Salmonella Serogroup A-E and Vi, Serogroup F-67,
Serogroup B, Serogroup C, Serogroup D, Serogroup E, Salmonella Derby). The Salmoporc ${ }^{\oplus}$ vaccine stain was differentiated from field strains of $S$. Typhimurium by a microbiological test called "IDT Salmonella Diagnostic Kit" which contains a nutrient broth which lacks adenine and histidine in which the vaccine strain does not grow and field strains do. No antimicrobial resistance testing was done on the isolated field strains.

\section{The Salmoporc ${ }^{\circledast}$ vaccination scheme}

Sows vaccinated for the first time were vaccinated twice with one dose $(1 \mathrm{ml}) 3$ weeks apart, approximately 6 and 3-weeks ante partum (ap). Consecutive vaccinations were done with one dose $(1 \mathrm{ml})$ at 3 weeks ante partum. Onset of immunity is 2 weeks after the second vaccination and duration of immunity is 24 weeks. Piglets were vaccinated twice orally, $1 \mathrm{ml}$ each, starting from 4 days of age, the second dose 21 days later. No antimicrobials were administered 5 days before and after vaccination. If treatment for Streptococcus suis infection was necessary, the vaccination was delayed until 5 days after the treatment was stopped. Onset of immunity is 2 weeks after the second vaccination and the duration of immunity in piglets is 19 weeks.

The vaccination protocol started at the end of August 2016 and continued until the end of the trial in November 2019. Thereafter, sows and gilts were vaccinated according to SPC, but newborn piglets were drenched only once at 5 days after birth.

\section{Data management and analysis}

Data entry and result analysis was done using Excel (Office Excel, Microsoft Office Professional Plus 2016). Data entry was checked by a second person and corrected where necessary. Data collected were sampling date, sample number, sample type (pooled, dust, sock), animal category (farrowing, pregnant sows, AI centre, weaned piglets, breeding gilts / growers-finishers), sampling location (compartment or corridor), Salmonella positive yes/ no, Salmonella Typhimurium positive yes/no, S. Typhimurium field strain or vaccine strain, and which type of Salmonella it was when not S. Typhimurium (e.g. serogroup C). A compartment or corridor was considered positive if any sample from that location was positive for Salmonella. Chi-square statistics or Fisher exact test were carried out using the calculators on the website Social Science Statistics (https://www.socscistatistics.com/ tests/chisquare/default2.aspx or https://www. socscistatistics.com/tests/fisher/default2.aspx).

\section{Results}

Clinical salmonellosis and antimicrobial use

Soon after the first vaccinated animals entered the nursery and subsequently the grow-finishing compartments, 


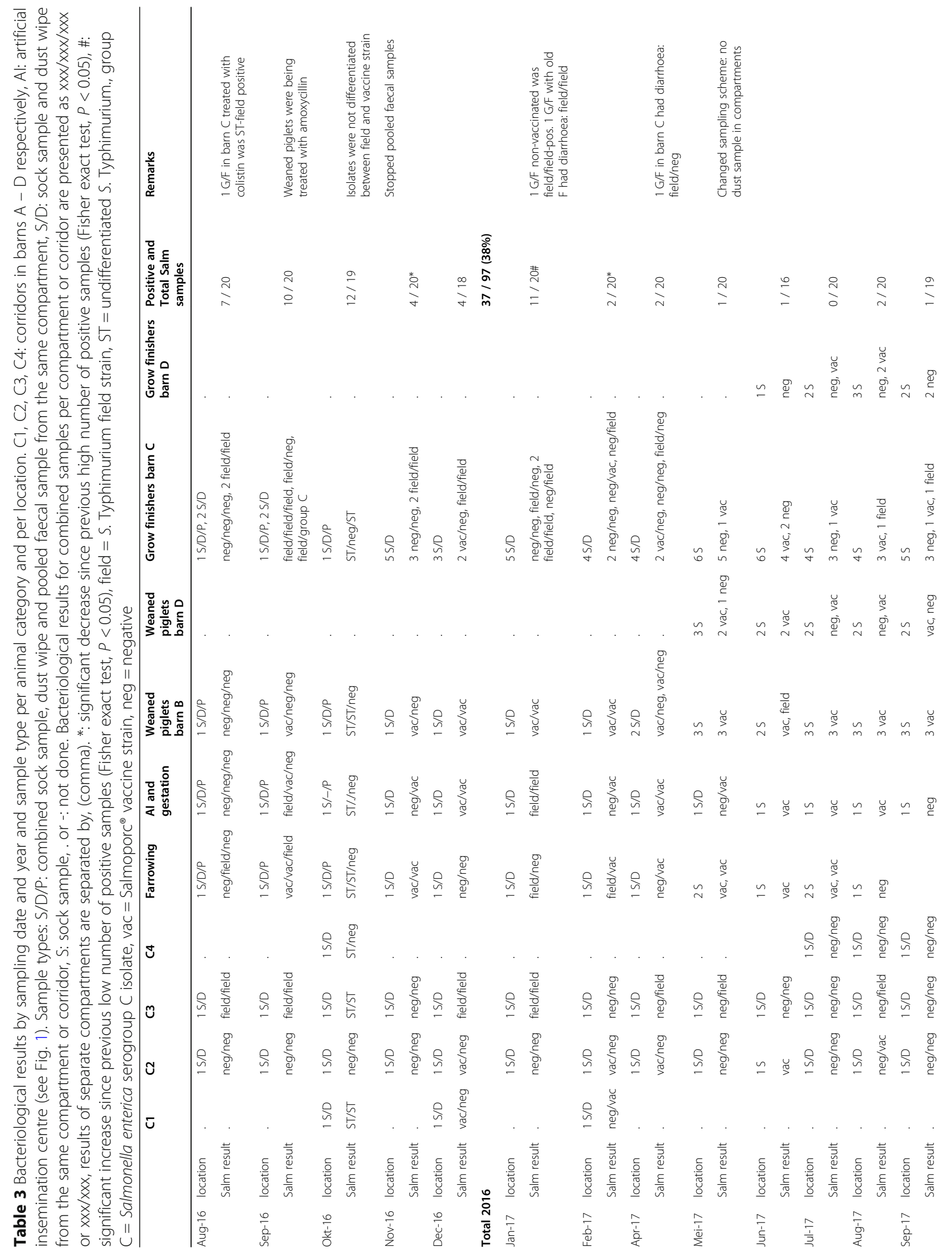


Wolf et al. Porcine Health Management

(2021) 7:43

Page 8 of 17

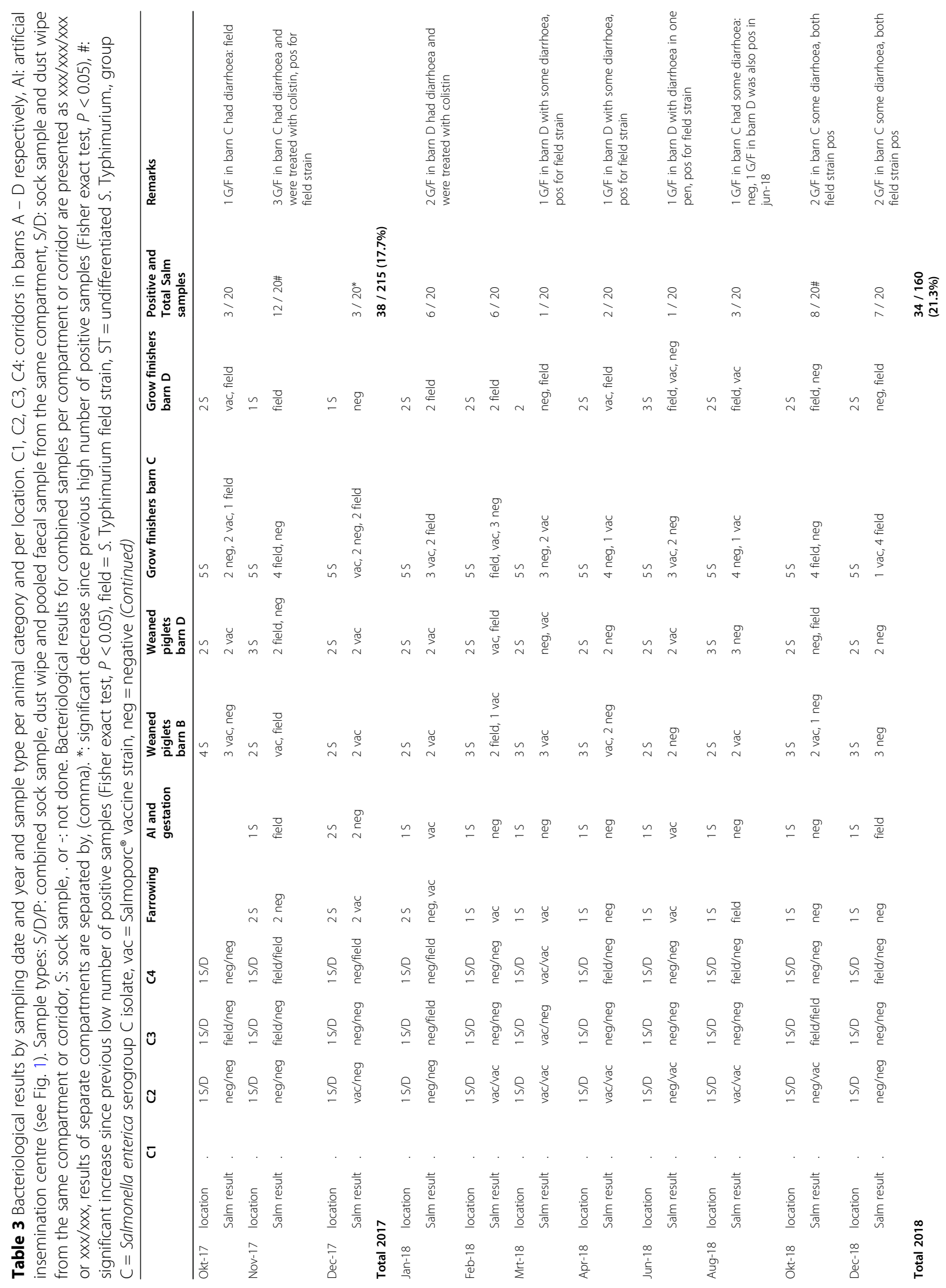




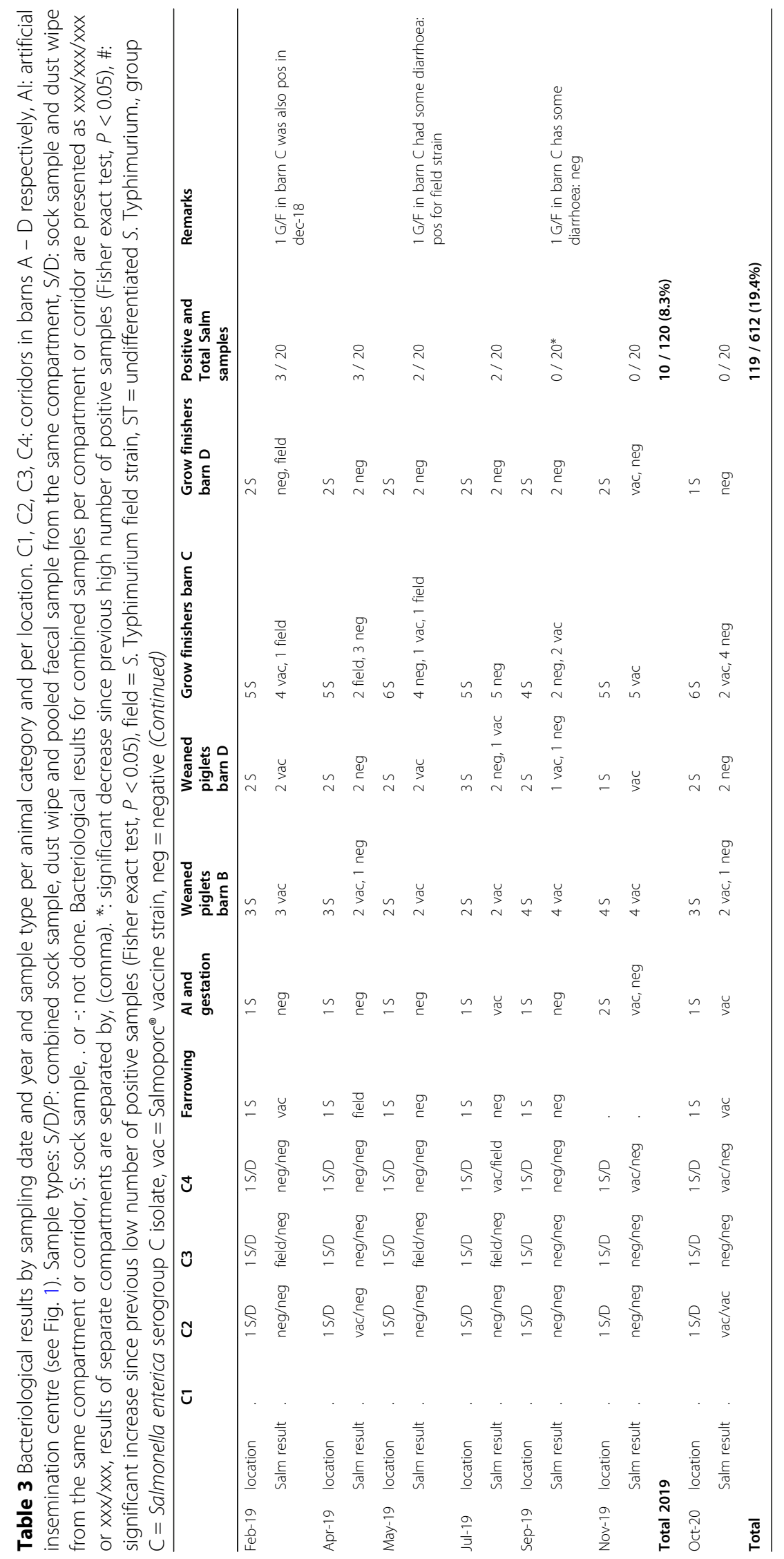


the clinical symptoms were reduced to a minimum and hardly any antimicrobial use was necessary (Fig. 2). The number of positive samples decreased significantly during the summer of 2017, compared to the fall of 2016 and January 2017 (Fisher exact test, $P<0.05,11$ out of 20 versus 1 out of 20)(Table 3, Fig. 3). However, during fall 2017 there was a period of increased diarrhoea in one compartment of finishers and gilts with a corresponding significant increase in Salmonella positive samples from several different locations (Fisher exact test, $P<0.05,3$ out of 20 versus 12 out of 20). After this period, the number of positive samples significantly decreased again during the spring and summer of 2018 (March $1 / 20$, April $2 / 20$ and June $1 / 20$ positive samples)(Fisher exact test, $P<0.05$ ). During fall and winter 2018/2019 the number of positive samples significantly increased again (Fisher exact test, $P<0.05,1$ out of 20 versus 8 out of 20). However, very few clinical signs were observed and only minimal use of colistin sulphate was necessary (Fig. 2, Table 3, Fig. 3). During spring and summer 2019 the number of positives significantly decreased again to finally 0 positive samples in September and November 2019 and October 2020 (Fisher exact test, $P<0.05$, 8 out of 20 versus 0 out of 20 ).

\section{Bacteriological samples}

A total of 612 samples were collected in the period from August 2016 to October 2020 over 31 samplings (Table 3, Fig. 3). In five of these, including the last four, no Salmonella field strains could be detected within compartments, although on two locations (corridors C2 and C3, September 2019) Salmonella field strains were still found (Table 3). The last three samplings were completely negative for Salmonella field strains.

In total 119 Salmonella field strains could be isolated of which 99 were Salmonella Typhimurium and one isolate was from Salmonella enterica serogroup C which was not typed further to serotype level (September 14th, 2016, Table 3). However, 19 isolates were $S$. Typhimurium which were not differentiated as field or vaccine strain. Twelve of these strains isolated on October 25th, 2016 could have been the vaccine strain, because the laboratory did not carry out the differentiation test. Salmoporc $^{\circ}$ vaccine strain was isolated in 197 samples, mostly from weaned piglets (Table 3 ).

A total of 86 pairs of sock and dust samples from corridors were collected. In 43 pairs both were negative, in 15 pairs both were positive, in 18 pairs only the sock and in 10 pairs only the dust was positive. The difference in the number of pairs in which either sock or dust was positive was not statistically significant (Chi-square, $P$ > 0.05). However, taking the dust sample in addition to the sock sample increased the prevalence by $11.6 \%$ from 38.4 to $50 \%$, thereby increasing the detection rate of the sampling method by more than $30 \%$. In the beginning of the trial 48 combinations of sock and dust samples were collected in compartments. In 19 cases both were positive and in 8 cases both were negative. In 13 cases only the sock sample was positive and in 8 cases only the dust sample was positive. The difference in the number of pairs in which either sock or dust was positive was not statistically significant (Chi-square, $P>0.05$ ). However,

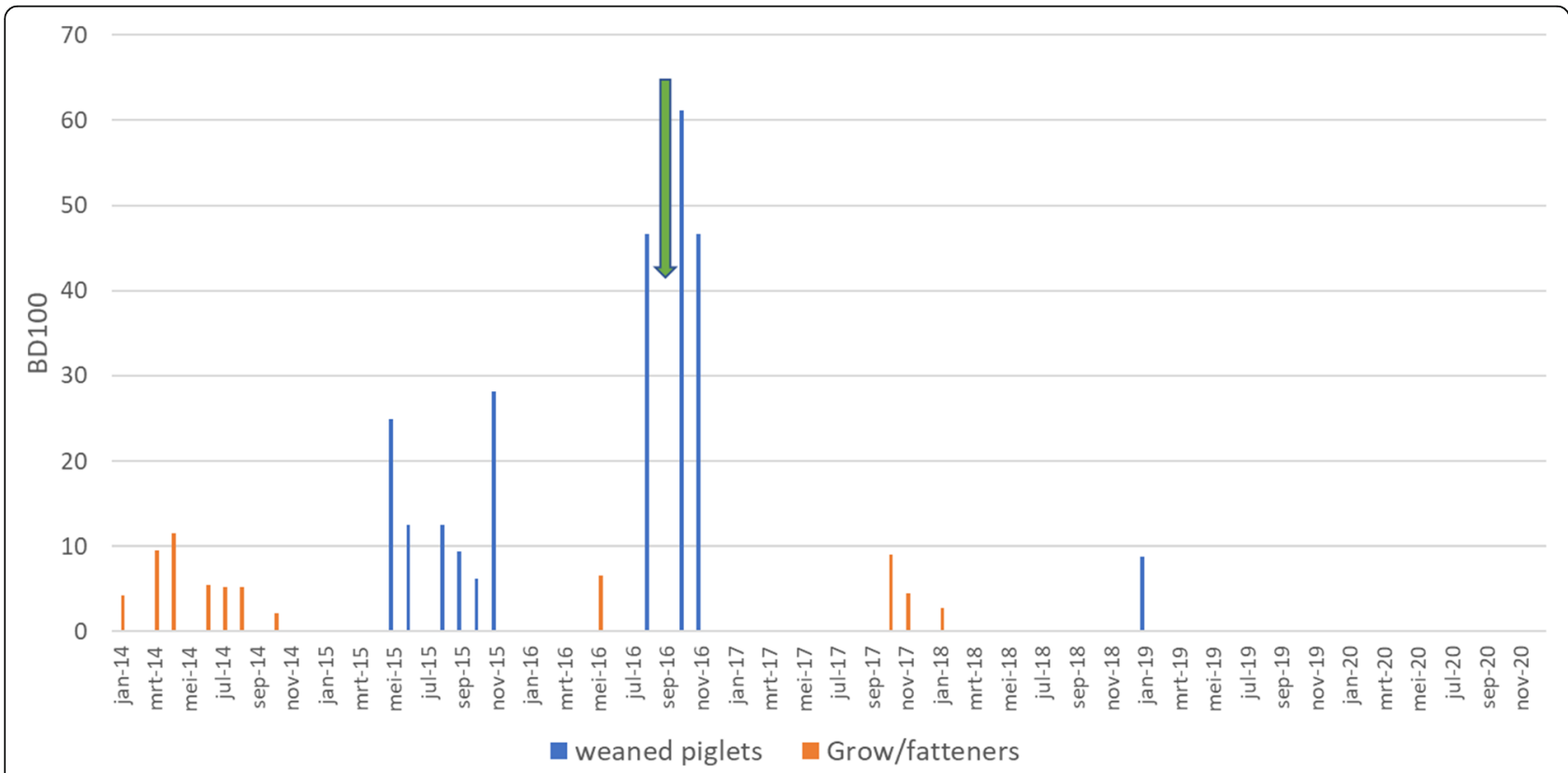

Fig. 2 Value of the Belgian antimicrobial treatment index (BD100, AMCRA) for colistin per month for treatment of clinical signs of salmonellosis in weaned piglets and grow/fatteners during the period January 2014 to December 2020 inclusive 


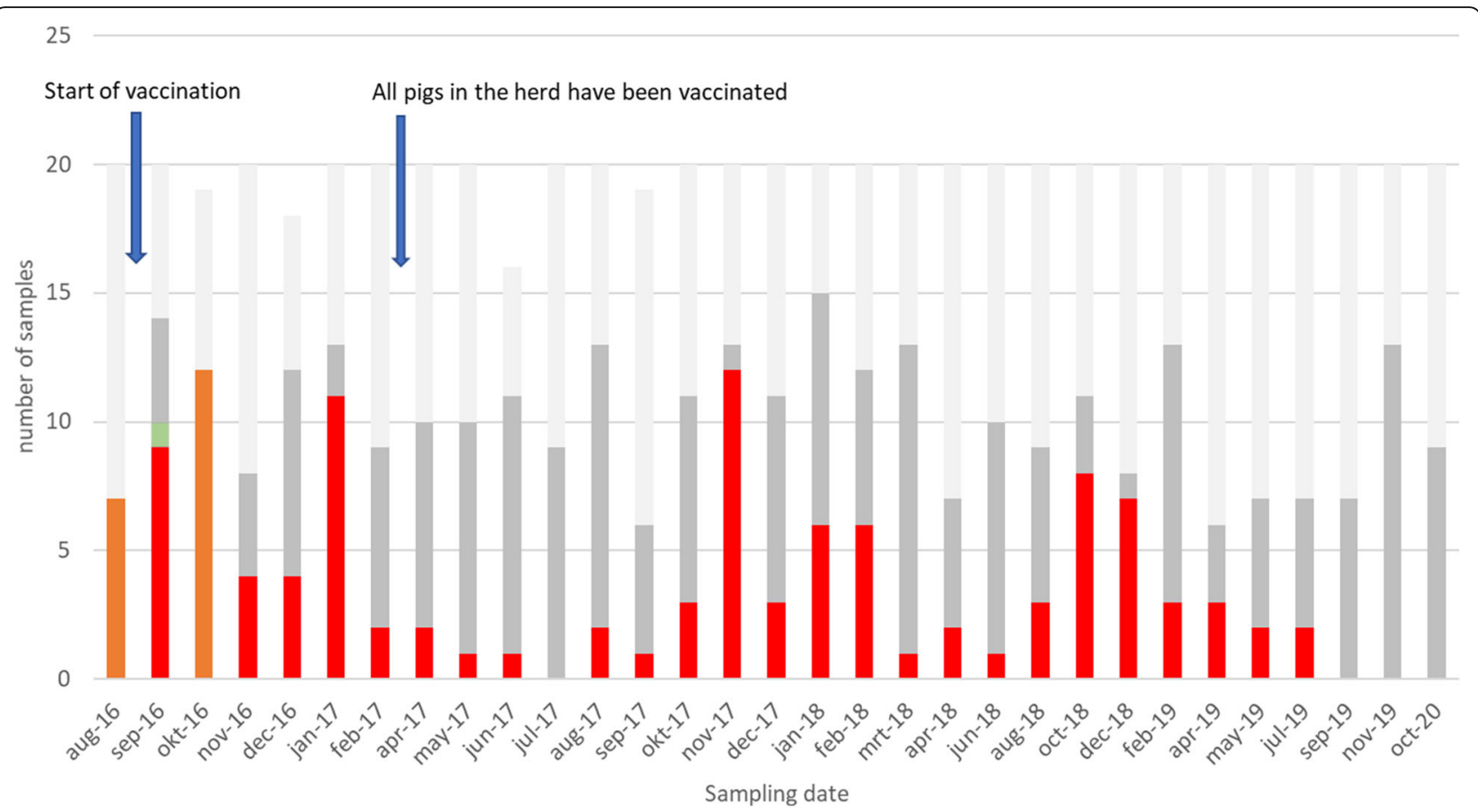

Fig. 3 Number of samples taken per sampling date in the period August 2016 to October 2020 differentiated by bacteriological testing result. Dark red bars: Salmonella Typhimurium not differentiated between field and vaccine strain, bright red bars: Salmonella Typhimurium field strains, green bar: Salmonella enterica serogroup C isolate, dark grey bars: Salmoporc ${ }^{\circledast}$ vaccine strain, light grey bars: negative samples. Start of vaccination in August 2016, last non-vaccinated fatteners have been delivered to the slaughterhouse in February 2017

by no longer collecting the dust sample in compartments, the prevalence dropped from 83.3 to $66.7 \%$ for field and vaccine strains combined, or from 41.7 to $35.4 \%$ for field strains only, thereby decreasing the detection rate of the sampling method by $15 \%$. In 11 samplings in compartments in addition to a sock and dust sample, a pooled faecal sample was collected. In 3 cases all samples were negative and in 1 case all were positive for field strain. In one case a field strain was found in the pooled faecal sample when in both the sock and the dust sample a vaccine strain was found, therefore finding 7 compartments to be positive, instead of 6 . This is an increase of the detection rate by $9 \%$. In one case the sock sample and the pooled faecal sample were positive, but the dust was negative. In one sample only the dust was positive. In 4 cases the pooled sample was negative when the sock and dust samples were positive. Comparing sock and pooled samples $(N=12$, Table 3$), 5$ sock samples were positive ( 1 field, 1 vaccine and $3 \mathrm{ST}$ ) where the pooled sample was negative, thereby increasing the chance of finding a Salmonella (field, S. Typhimurium or vaccine) from $3 / 12$ to $8 / 12$ using sock samples (Fisher exact test, $P=0.0995$ ).

In total $74 \mathrm{~S}$. Typhimurium field strains were isolated in compartments housing pigs. The majority (56/74, $75.7 \%)$ were found in rearing gilts / finishers compartments, 7\% (5/74) in farrowing compartments, 7\% (5/74) in the gestating sow compartment and the AI centre, and $10.8 \%(8 / 74)$ in weaned piglets' compartments. The samples of the herd visit of the 28th of May 2019 were split and one part was sent to AniCon Laboratory (Anicon Labor GmbH, Höltinghausen, Germany), who ran a multiplex PCR as part of the validation of the test kit (Kylt ${ }^{\circ}$ Salmonella Typhimurium DIVA Real-Time PCR, www.kylt.eu). The results were the same as from the microbiological lab in Hannover detecting no simultaneous presence of field and vaccine strains in the same samples.

\section{Discussion}

This case describes a pig herd which experienced outbreaks of clinical salmonellosis caused by Salmonella Typhimurium in weaned piglets, growers, breeding gilts and finishers, which started vaccination with a live attenuated $S$. Typhimurium vaccine $\left(\right.$ Salmoporc $^{\circ}$ ) in August 2016 in sows, piglets and replacement gilts. Other previously tried interventions, such as strict all-in/all-out, cleaning and disinfection, medication and adding organic acids to the feed and/or drinking water, did not improve the clinical situation. These outbreaks were mostly in finisher pigs and characterised by diarrhoea, loss of appetite during approx. one week, loss of bodyweight and in some cases up to $2 \%$ mortality. A previous case report demonstrated that clinical outbreaks of salmonellosis 
can cost up to $€ 4.60$ per pig sent to slaughter during a 3 month period in which the outbreak occurred [8]. Extrapolated to the herd in this study, this means a loss of approximately $€ 17,000$.- net income in 2015 due to salmonellosis. Vaccinating the pigs at this herd costs about $€ 15,000$.- per year, not counting the costs of labour, saved antimicrobial costs and the psychological burden of having a serious pig disease in your farm. In the long term, the aim would be to have no more Salmonella in the weaned piglets and grow/finishers and being able to stop vaccinating the piglets. Vaccinating only the sows and gilts is only a fraction of the costs, but can be considered as an insurance premium against re-emerging or re-introduction of Salmonella Typhimurium by e.g. introduction of breeding stock or visitors. The outbreaks in our study herd were treated with colistin sulphate, which is now considered an antimicrobial reserved for last resort treatment in humans and can only be used in pigs under strict regulation [38]. Although clinically effective for the treated batches of pigs, an increasing amount of colistin was needed to treat clinically sick pigs (Fig. 2) to a point were weaned piglets were treated more than 60 out of 100 days in October 2016. This is not a sustainable situation from an animal welfare point of view, a financial perspective of the farmer and the perspective of emerging antimicrobial resistance against polymyxins [39-41]. Because antimicrobial therapy only reduces shedding once treatment of clinically sick pigs has started, untreated pigs can shed Salmonella, resulting in rapid spread to other compartments and corridors of the farm. Rapid spread was seen in this herd after the clinical outbreak in the fall and winter of 2017/2018 and $2018 / 2019$, even though clinical signs might be limited to only one or two compartments and at a level where the farmer and the veterinarian didn't find antimicrobial treatment necessary (Figs. 2 and 3, Table 3). As soon as vaccinated piglets, growers and finishers entered the barns, the clinical situation improved and as a result the antimicrobial use decreased dramatically, which is illustrated in Fig. 2. The number of Salmonella-positive samples significantly decreased in spring and summer of 2017, 10 months after the start of the vaccination, from up to $11 \mathrm{~S}$. Typhimurium field strain positive samples to no positive samples in July 2017 and no S. Typhimurium field strain found in the compartments with gilts / finishers in May, June and July 2017 (Table 3). Such a fast improvement after the start of the vaccination has been described before [30, 31]. However, one negative sampling cannot be considered as sufficient proof that the prevalence is low enough to stop vaccinating piglets. Therefore the vaccination and sampling were continued, until October 2020, showing that the significant increases of the number of positive samples in the fall and winter of $2017 / 2018$ and 2018/2019, did not repeat itself in the fall of 2019 and 2020.
Three different sampling schemes (I, II, III) were used for collecting pooled faecal, sock and dust samples, because the sampling scheme was improved during this study based on increased knowledge about the capacity of different sample types to detect Salmonella in a pig herd environment, including the results of this study [36]. The dust samples had very little added value in compartments where animals were present $(<5 \%$ more positive compartments), however, they do have added value in corridors, which tend to have very little faecal contamination on the floor. Therefore, we decided to use only sock samples in compartments where animals were housed and combined a sock and dust sample in corridors in the final Scheme III. This way we could sample more compartments and corridors with the same total number of samples (17 instead of 10 for a total number of 20 samples), increasing the detection rate of the sampling, and putting more emphasis on sampling compartments of weaned piglets and compartments of growers and finishers and/or rearing gilts.

The possible explanation that sock samples were found to be more sensitive than pooled faecal samples (not only based on the results of this farm) is probably because when using a sock, much more surface is covered and therefore more individual droppings are being sampled. This method increases the chance of sampling a dropping from a pig excreting Salmonella. A pooled faecal sample probably contains more faecal material than a sock, thereby increasing the chance of finding Salmonella when present [42], but apparently this is overcompensated by the chance of sampling a positive dropping. Also, using pre-enrichment and selective enrichment during culture, makes it possible to detect the presence of very small numbers of Salmonella in a sample $[43,44]$.

Using the described microbiological method, it is not possible to infer anything about the number of Salmonella bacteria present in the sample. The use of a semiquantitative method, like for instance real time PCR, might be able to provide information about the number of Salmonella bacteria present in the sample. This (semi) quantitative test could provide information about the level of shedding of Salmonella, for example very low in sows which have been vaccinated or very high in clinical situations, as noted by Davies et al. [30] or Jensen et al. [45]. This would give more information about the true status of the herd. These are possible subjects for further study.

In several samplings where we didn't find field strains of $S$. Typhimurium, we did find vaccine strain. We cannot rule out the possibility that in samples where both field and vaccine strains were present, a colony of vaccine strain was picked for typing instead of a colony of field strain, since only one colony per sample was typed. 
When more colonies are picked, several serotypes can be found within one sample [46]. Alternatively, a multiplex PCR that can detect simultaneously the DNA of field and vaccine strain, next to general Salmonella spp. DNA, would also solve this problem (e.g. Kylt Salmonella Typhimurium DIVA Real-Time PCR, www.kylt.eu). The vaccine strain can be found in the environment for between 1 and 2 months after stopping vaccination (field data from another farm), however, it is not clear whether this is survival per se or continued shedding by vaccinated animals, which has been shown for 6 weeks after vaccination in experimental setting.

Serology as an additional tool to monitor the Salmonella status was not performed, because the current Salmonella LPS-ELISA's cannot differentiate between antibodies due to vaccination or field infection, making interpretation of the results impossible [26]. Differentiation has been done before by Selbitz et al. [35], but these tests were not available to us. Piglets orally vaccinated with Salmoporc ${ }^{\bullet}$ will become serologically positive for a few weeks, but would be serologically negative at slaughter, if no boostering as a result of infection with field strains would take place [47]. Theoretically, boostering as a result of additional contact to vaccine strain at a later age might also be possible, if internal biosecurity between age categories is not optimal, as we found in this study where we found vaccine strain in barn $\mathrm{C}$ repeatedly (Table 3). On a national level (e.g. DK, DE and NL [48-50]), general LPS-ELISA's are used to monitor and categorize pig herds for Salmonella. In those countries the inability to differentiate antibodies caused by vaccination and/or infection might lead to problems with such a categorization, however, under the current circumstances where vaccination is not obligatory, only herds in categories II or III would consider vaccination and they are in the risk categories to begin with. Collecting mesenteric lymph nodes at the slaughterhouse might have been an additional method to check for the presence of field strain Salmonella, because pigs can carry Salmonella in their lymph nodes without shedding Salmonella. However, contamination and infection during the period of transport and holding at the slaughterhouse [51] would make sequencing of isolates necessary to differentiate herd strains from those acquired after leaving the farm, which is very labour intensive and costly. Additionally, it has already been shown that vaccination significantly reduces the infection of internal organs including gut associated lymph nodes [47], resulting in a reduced number of contaminated mesenteric lymph nodes at slaughter as a result of vaccination [35]. Finally, any carriers that might start shedding again would have been found during the next sampling, as we found in the fall and winter of 2017/2018 and 2018/ 2019. We were specifically interested in the Salmonella contamination of the herd environment. Salmonella can survive for a very long time, up to 50 months in the environment, for example in slurry [52] or dust [53, 54]. This means that compartments and corridors that are not thoroughly cleaned and disinfected, can become a source of infection for pigs as soon as they enter these compartments, or as in this study, walk along contaminated corridors. The difficulty of effective cleaning and disinfection is well documented for lairages at slaughterhouses ( [55-57] and transport lorries [58], but this also applies to corridors and compartments within farms [59-62] and this study (Table 3). Common practice in pig farms is not to use power washers in compartments above about $1.5 \mathrm{~m}$ height, because of the power plugs, feed, water and power lines, lights and ventilator(s), which are located near the ceiling. The dust that settles on these structures is often contaminated with Salmonella, as the results of this study demonstrate. In poultry farms, sampling dust is a generally accepted method to demonstrate contamination with Salmonella [53, 63]. This means that pig farms can be heavily contaminated with Salmonella by Salmonella-shedding pigs. Common cleaning and disinfection procedures are in many cases not enough to get rid of all Salmonella [60]. Additionally, compartments are almost never cleaned all at the same time because they are only emptied at the same time if an all-in/all-out management is practiced at barn or even herd level, which was not the case in this study. This means that Salmonella contamination can easily be carried from one compartment to another by the farmer, employees, visitors, flies, mice, rats or interconnected slurry pits located below the slats of compartments. This is the reason that Salmonella's, once introduced into a farmhouse, can persist for a long time (at least 3 years for example for monophasic $S$. Typhimurium [64]). Together with the regular introduction of infected animals, this is the main reason for the persistence of Salmonella within pig farms. In this particular farm, introduction of infected animals did not occur, however the persistence of contamination within the buildings and pigs is very likely, as no new serotype was found during this study which could be the result of new introductions. We cannot exclude that, after a completely negative sampling, the field strains that were found were new introductions, however, we do not consider this likely. Only part or whole genome sequencing (WGS) would be able to demonstrate whether these were different strains, however, this was not part of this study.

Vaccination with Salmoporc ${ }^{\circ}$ was used to increase the immunity of pigs and thereby decreasing the chance of infection under the given circumstances. Further, in the event of infection, vaccinated pigs will shed less Salmonella and during a shorter period, leading to a lower overall contamination of the environment. By continuing the 
vaccination for a longer period, the contamination of the environment decreases to a point where Salmonella can no longer be detected, such as in this case. Given the severe clinical situation before the start of vaccination and the rapid decline during the summer of 2017 we consider it unlikely that a similar effect could have been achieved without vaccination. The rise in the number of positive samples during the fall and winter of $2017 / 2018$ was probably caused by the farmer who relocated some almost-ready-to-breed gilts to a compartment with heavy finishers. In this compartment a water pipeline broke and a lot of water leaked into the slurry pit, resulting in the manure coming up above the slats of the floor because of which the pigs were standing and lying in the slurry. Consequently some pigs developed diarrhoea and one heavy gilt died. No further diagnostic was performed. This was followed by a temporary peak in the number of positive samples in the herd in November $2017(12 / 20$, Table 3$)$. This again shows, that in noncleaned and disinfected areas of the farm (underneath the slatted floor) Salmonella can survive for a long time and non-expected breakdowns can lead to recontamination. The lack of internal biosecurity protocols, including application by the farmer himself, probably assisted the Salmonella spread to the corridors (Table 3) and other compartments. Soon after the issues were solved, the number of positive samples dropped again to only one or two positive samples in the samplings in March, April and June 2018. However, again in fall and winter 2018/ 2019 the number of positive samples rose to 8 and 7 positives out of 20 each in October and December 2018 respectively. No clear clinical signs were observed, but some diarrhoea was seen and some colistin sulphate was used to treat the diarrhoea symptoms (Fig. 2, Table 3). No clear explanation why the number of positive samples rose in this fall and winter was found.

Salmoporc ${ }^{\circ}$ vaccine strain has been found in almost all samplings during this study. Because we took sock and dust samples, we cannot say whether this is spilt vaccine or if this was coming from orally vaccinated animals. This result corresponds with results found by Peeters et al. 2019 [28]. In our opinion this does not constitute a public health risk, because the vaccine strain is considered a level 1 biological by the central committee for biological safety in Germany (Zentrale Kommission für biologische Sicherheit (ZKBS)), and therefore safe for humans and animals, also due to its stable double attenuation. Extensive screening of approximately 14,000 human isolates of Salmonella Typhimurium by the German reference institute for Salmonella (Robert Koch Institute) in the period from 2002 to 2016 showed only one isolation of the vaccine strain, which was the result of accidental self-injection, despite extensive use of this vaccine in pigs in Germany.
Attempts have been made to control Salmonella in the pig industry, for example the Danish control program [48], the Belgian control program by Royal decree, UK ZAP program [65], the German QS system [49], but some were stopped due to lack of improvement (UK ZAP program and Belgian program) or showed very slow progress [66] (https://www.q-s.de/ pressemeldungen/anzahl-betriebe-erhoehtessalmonellenrisiko-gering.html). However, none of these included the use of vaccination as a means of control. In Denmark the strategy is now to control this risk at the slaughterhouse during the slaughter process [67]. Cargnel et al. [68] come to the same conclusion, however assuming that vaccination with a live vaccine only reduces the colonisation and excretion of vaccinated animals by 29.96\%. Several longer term studies and this study did show that the overall prevalence of $S$. Typhimurium went down to a very high extent $[30,31]$. Together with the results of this study, this gives a strong indication that, as in poultry, adding vaccination to the Salmonella control programs might result in a reduction of the number of farms 'at risk' and ultimately reduce the number of infections in consumers of pork and pork products.

\section{Abbreviations \\ Al: Artificial Insemination; AMCRA: Knowledge centre for antimicrobial use and resistance in animals, www.amcra.be; Approx.: Approximately; CODA- CERVA: Veterinary and Agrochemical Research Centre, Belgium; \\ DGZ: Diergezondheidszorg Vlaanderen (Animal Health Service, Belgium); ml: Millilitre; Pos: Positive; S: Salmonella; ST: Salmonella Typhimurium; S Typh: Salmonella Typhimurium; Neg: Negative}

\section{Acknowledgements}

The authors would like to acknowledge the farmer for his contribution to this study. We thank the Microbiological Institute of the University of Hannover for analysing the bacteriological samples for the presence of Salmonella. We thank IDT Biologika GmbH and Ceva Santé Animale BV for supporting this study.

\section{Authors' contributions}

PvdW, KLJ and VS: study design, PvdW, MM and EL: sampling, PvdW and MM: data entry and analysis, GT and EG: veterinary care of the farm. PvdW was a major contributor in writing the manuscript. All authors read and approved the final manuscript.

\section{Authors' information}

PvdW, MM, EL, KLJ and VS were employed by either IDT Biologika or Ceva Santé Animale during this study.

\section{Funding}

The costs of sampling materials, sampling, sample shipment and sample analysis was paid for by IDT Biologika Benelux BV before July 1st, 2019 and after that by Ceva Santé Animale The Netherlands. The piglet vaccine was supplied for free to the veterinary practice. The sow vaccine was paid for by the farmer.

\section{Availability of data and materials}

The datasets used and/or analysed during the current study are available from the corresponding author on reasonable request. 


\section{Declarations}

\section{Ethics approval and consent to participate}

The owner of this farm participated in this study at his own request and a user experience trial agreement was signed by the veterinarian responsible for the veterinary service on this farm. No animal ethics permission was obtained because only environmental samples were collected.

\section{Consent for publication}

Not applicable.

\section{Competing interests}

The authors declare that they have no competing interests.

\section{Author details}

${ }^{1}$ Ceva Santé Animale BV, Naaldwijk, The Netherlands. ${ }^{2}$ Ceva Santé Animale S.A., Brussel, Belgium. ${ }^{3}$ Veterinary Practice "VarkensArtsenZuid", Panningen, The Netherlands. ${ }^{4} \mathrm{Ceva}$ Tiergesundheit $\mathrm{GmbH}$, Düsseldorf, Germany.

\section{Received: 5 February 2021 Accepted: 3 July 2021}

Published online: 23 July 2021

\section{References}

1. Ferrari RG, DKA R, Cunha-Neto A, Mano SB, EES F, Conte-Junior CA. Worldwide epidemiology of salmonella serovars in animal-based foods: a meta-analysis. Appl Environ Microbiol. 2019;85(14) [cited 2020 May 13]. Available from: https://www.ncbi.nlm.nih.gov/pmc/articles/PMC6606869/.

2. Anonymous. The European Union One Health 2018 Zoonoses Report - 2019 - EFSA Journal - Wiley Online Library. [cited 2020 May 13]. Available from: https://efsa.onlinelibrary.wiley.com/doi/10.2903/j.efsa.2019.5926

3. Vlaanderen F, Uiterwijk M, Cuperus T, Keur I, De Rosa M, Rozendaal H, et al. Staat van Zoönosen 2018. Bilthoven: RIVM; 2019. p. 92. [cited 2020 May 13]. Report No.: 2019-0185. Available from: https://rivm.openrepository.com/ha ndle/10029/623615

4. Wilkins EGL, Roberts C. Extraintestinal salmonellosis. Epidemiol Infect. 1988; 100(3):361-8 [cited 2020 Jun 25]. Available from: https://www.cambridge. org/core/journals/epidemiology-and-infection/article/extraintestinal-sa Imonellosis/78832FF29D3817D9D769994DEB153E57.

5. Boyen F, Haesebrouck F, Maes D, Van Immerseel F, Ducatelle R, Pasmans F. Non-typhoidal Salmonella infections in pigs: a closer look at epidemiology, pathogenesis and control. Vet Microbiol. 2008;130(1-2):1-19. https://doi. org/10.1016/j.vetmic.2007.12.017.

6. Carlson SA, Barnhill AE, Griffith RW. Salmonellosis. In: Diseases of Swine. 10th ed. Chichester, West Sussex: Wiley-Blackwell; 2012. p. 983.

7. van der Wolf PJ, Vercammen TJ, Geene JJ, van Exsel AC, Peperkamp NH, Voets MT, et al. Salmonella typhimurium DT104 septicaemia with meningitis in neonatal piglets. Vet Q. 2001;23(4):199-201. https://doi.org/10.1080/01 652176.2001 .9695113$.

8. van der Wolf $\mathrm{P}$, van den Bergh M. Clinical salmonellosis in a finishing herd, a case report. In: International Conference on the Epidemiology and Control of Biological, Chemical and Physical Hazards in Pigs and Pork. Rohnert Park, CA, United States: lowa State University, Digital Press; 2005. p. 126-8. [cited 2020 Jun 23]. Available from: https://lib.dr.iastate.edu/safepork/2005/allpa pers/35/.

9. Berends BR, Urlings HA, Snijders JM, Van Knapen F. Identification and quantification of risk factors in animal management and transport regarding Salmonella spp. in pigs. Int J Food Microbiol. 1996;30(1-2):37-53. https://doi. org/10.1016/0168-1605(96)00990-7.

10. Bahnson PB, Fedorka-Cray PJ, Ladely SR, Mateus-Pinilla NE. Herd-level risk factors for Salmonella enterica subsp. enterica in U.S. market pigs. Prev Vet Med. 2006;76(3-4):249-62. https://doi.org/10.1016/j.prevetmed.2006.05.009.

11. De Lucia A, Ostanello F. On-farm risk factors associated with Salmonella in pig herds. Large Anim Rev. 2020;26(3):133-40 [cited 2020 Jun 16]. Available from: https://www.largeanimalreview.com/index.php/lar/article/view/124.

12. Davies PR, Morrow WE, Jones FT, Deen J, Fedorka-Cray PJ, Gray JT. Risk of shedding Salmonella organisms by market-age hogs in a barn with openflush gutters. J Am Vet Med Assoc. 1997;210(3):386-9.

13. Davies PR, Scott Hurd H, Funk JA, Fedorka-Cray PJ, Jones FT. The role of contaminated feed in the epidemiology and control of Salmonella enterica in pork production. Foodborne Pathog Dis. 2004;1(4):202-15. https://doi. org/10.1089/fpd.2004.1.202.
14. Lo Fo Wong DMA, Dahl J, Stege H, van der Wolf PJ, Leontides L, von Altrock A, et al. Herd-level risk factors for subclinical Salmonella infection in European finishing-pig herds. Prev Vet Med. 2004;62(4):253-66. https://doi. org/10.1016/j.prevetmed.2004.01.001

15. Wales AD, Cook AJC, Davies RH. Producing Salmonella-free pigs: a review focusing on interventions at weaning. Vet Rec. 2011;168(10):267-76 [cited 2020 May 12]. Available from: https://veterinaryrecord.bmj.com/content/1 68/10/267.

16. Farzan A, Friendship RM, Dewey CE, Poppe C, Funk J. Evaluation of the risk factors for shedding Salmonella with or without antimicrobial resistance in swine using multinomial regression method. Zoonoses Public Health. 2010; 57(Suppl 1):85-93. https://doi.org/10.1111/j.1863-2378.2010.01357.x.

17. Nollet N, Maes D, De Zutter L, Duchateau L, Houf K, Huysmans K, et al. Risk factors for the herd-level bacteriologic prevalence of Salmonella in Belgian slaughter pigs. Prev Vet Med. 2004;65(1-2):63-75. https://doi.org/10.1016/j. prevetmed.2004.06.009.

18. Heier BT, Hopp P, Kalberg S, Bergsjo B. Salmonella. 2018 [cited 2020 May 15]. Available from: https://www.vetinst.no/en/surveillance-programmes/sa Imonella

19. Anonymous. Salmonella in pigs. 2020 [cited 2020 May 15]. Available from: https://www.sva.se/en/our-topics/feed-safety/salmonella-in-pigs/

20. van der Wolf PJ, Wolbers WB, Elbers AR, van der Heijden HM, Koppen JM, Hunneman WA, et al. Herd level husbandry factors associated with the serological Salmonella prevalence in finishing pig herds in the Netherlands. Vet Microbiol. 2001;78(3):205-19. https://doi.org/10.1016/S0378-1135(00)002 94-7.

21. van der Wolf PJ, Bongers JH, Elbers AR, Franssen FM, Hunneman WA, van Exsel AC, et al. Salmonella infections in finishing pigs in the Netherlands: bacteriological herd prevalence, serogroup and antibiotic resistance of isolates and risk factors for infection. Vet Microbiol. 1999;67(4):263-75. https://doi.org/10.1016/S0378-1135(99)00054-1

22. van der Wolf PJ, Lo Fo Wong DM, Wolbers WB, Elbers AR, van der Heijden $H M$, van Schie FW, et al. A longitudinal study of Salmonella enterica infections in high-and low-seroprevalence finishing swine herds in the Netherlands. Vet Q. 2001;23(3):116-21. https://doi.org/10.1080/01652176.2 001.9695096.

23. Anonymous. Analysis of the baseline survey on the prevalence of Salmonella in holdings with breeding pigs in the EU, 2008 - Part A: Salmonella prevalence estimates. EFSA J. 2009;7(12):1377 [cited 2020 May 12]. Available from: https://efsa.onlinelibrary.wiley.com/doi/abs/10.2903/j. efsa.2009.1377.

24. Ugolini M, Gerhard J, Burkert S, Jensen KJ, Georg P, Ebner F, et al. Recognition of microbial viability via TLR8 drives TFH cell differentiation and vaccine responses. Nat Immunol. 2018;19(4):386-96 [cited 2021 May 6]. Available from: http://www.nature.com/articles/s41590-018-0068-4.

25. Roesler U, Stief M, Lindner T, Truyen U, Selbitz H-J. Microbial and serological effects of vaccination of sows and suckling piglets with an attenuated live Salmonella vaccine. In: International Conference on the Epidemiology and Control of Biological, Chemical and Physical Hazards in Pigs and Pork. Heraklion, Crete, Greece: Iowa State University, Digital Press; 2011. p. 130 [cited 2021 May 6]. Available from: https://lib.dr.iastate.edu/safepork/2011/a Ilpapers/35/.

26. Theuss T, Ueberham E, Lehmann J, Lindner T, Springer S. Immunogenic potential of a Salmonella Typhimurium live vaccine for pigs against monophasic Salmonella Typhimurium DT 193. BMC Vet Res. 2018;13(1): 343.

27. Springer S, Lindner T, Steinbach G, Selbitz HJ. Investigation of the efficacy of a genetically-stabile live Salmonella typhimurium vaccine for use in swine. Berl Munch Tierarztl Wochenschr. 2001;114(9-10):342-5.

28. Peeters L, Dewulf J, Boyen F, Brossé C, Vandersmissen T, Rasschaert G, et al. Bacteriological evaluation of vaccination against Salmonella Typhimurium with an attenuated vaccine in subclinically infected pig herds. Prev Vet Med. 2019:104687 [cited 2020 Jun 23]. Available from: http://www. sciencedirect.com/science/article/pii/S0167587719300480.

29. De Ridder L, Maes D, Dewulf J, Butaye P, Pasmans F, Boyen F, et al. Use of a live attenuated Salmonella enterica serovar Typhimurium vaccine on farrowto-finish pig farms. Vet J Lond Engl 1997. 2014;202(2):303-8.

30. Davies R, Gosling RJ, Wales AD, Smith RP. Use of an attenuated live Salmonella typhimurium vaccine on three breeding pig units: a longitudinal observational field study. Comp Immunol Microbiol Infect Dis. 2016:46:7-15. https://doi.org/10.1016/j.cimid.2016.03.005. 
31. Smith RP, Andres V, Martelli F, Gosling B, Marco-Jimenez F, Vaughan K, et al. Maternal vaccination as a Salmonella Typhimurium reduction strategy on pig farms. J Appl Microbiol. 2018;124(1):274-85 [cited 2020 Jun 23]. Available from: https://sfamjournals.onlinelibrary.wiley.com/doi/abs/10.1111/ jam.13609.

32. Nielsen B, Baggesen D, Bager F, Haugegaard J, Lind P. The serological response to Salmonella serovars typhimurium and infantis in experimentally infected pigs. The time course followed with an indirect anti-LPS ELISA and bacteriological examinations. Vet Microbiol. 1995;47(3):205-18 [cited 2021 May 6]. Available from: https://www.sciencedirect.com/science/article/pii/03 78113595001131.

33. van der Wolf PJ, van Schie FW, Elbers AR, Engel B, van der Heijden HM, Hunneman WA, et al. Administration of acidified drinking water to finishing pigs in order to prevent Salmonella infections. Vet Q. 2001;23(3):121-5. https://doi.org/10.1080/01652176.2001.9695097.

34. Lindner T, Springer S, Selbitz H-J. The use of a Salmonella Typhimurium live vaccine to control Salmonella Typhimurium in fattening pigs in field and effects on serological surveillance. Int Conf Epidemiol Control Biol Chem Phys Hazards Pigs Pork. 2007; Available from: https://lib.dr.iastate.edu/sa fepork/2007/allpapers/63.

35. Selbitz H-J, Springer S, Lindner T, Holubek R, Lauterbach L, Rüdiger H. Immunprophylaxe von Salmonelleninfektionen und Salmonellosen der Tiere. Tierärztl Prax Ausg G Großtiere Nutztiere. 2006;34(2):126-32 [cited 2020 May 13]. Available from: http://www.thieme-connect.de/DOI/DOI?10.1 055/s-0037-1621054.

36. van der Wolf PJ, Koenders K, Gotter V. Analysis of sock, swab and fecal samples for presence of Salmonella from sow farms in The Netherlands. In: Proceedings of the 9th European Symposium of Porcine Health Management. Prague: European Symposium of Porcine Health Management; 2017. p. BBD-043. page 218.

37. Park SH, Kim HJ, Cho WH, Kim JH, Oh MH, Kim SH, et al. Identification of Salmonella enterica subspecies I, Salmonella enterica serovars typhimurium, Enteritidis and Typhi using multiplex PCR. FEMS Microbiol Lett. 2009;301(1): 137-46. https://doi.org/10.1111/j.1574-6968.2009.01809.x.

38. Anonymous. Amcra | Adviezen en wetgeving. [cited 2020 Jul 7]. Available from: https://amcra.be/nl/adviezen-en-wetgeving/

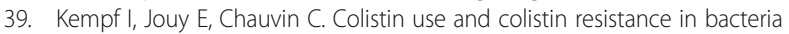
from animals. Int J Antimicrob Agents. 2016;48(6):598-606. https://doi.org/1 0.1016/j.jantimicag.2016.09.016.

40. Poolperm P, Tangkoskul T, Seenama C, Maknakhon N, Thamlikitkul V. Association between the use of colistin for short-term treatment of gram-negative bacterial infections and the emergence of colistinresistant Enterobacteriaceae in swine from selected swine farms in Thailand. PLoS One. 2020;15(10):e0238939. https://doi.org/10.1371/journa I.pone.0238939.

41. Carattoli A, Villa L, Feudi C, Curcio L, Orsini S, Luppi A, et al. Novel plasmidmediated colistin resistance mcr-4 gene in Salmonella and Escherichia coli, Italy 2013, Spain and Belgium, 2015 to 2016. Euro Surveill Bull Eur Sur Mal Transm Eur Commun Dis Bull. 2017;22(31):30589.

42. Funk JA, Davies PR, Nichols MA. The effect of fecal sample weight on detection of Salmonella enterica in swine feces. J Vet Diagn Investig Off Publ Am Assoc Vet Lab Diagn Inc. 2000;12(5):412-8. https://doi.org/10.11 77/104063870001200504.

43. Hoorfar J, Baggesen DL. Importance of pre-enrichment media for isolation of Salmonella spp. from swine and poultry. FEMS Microbiol Lett. 1998;169(1): 125-30. https://doi.org/10.1111/j.1574-6968.1998.tb13308.x.

44. Hoorfar J, Mortensen AV. Improved culture methods for isolation of Salmonella organisms from swine feces. Am J Vet Res. 2000;61(11):1426-9. https://doi.org/10.2460/ajvr.2000.61.1426.

45. Jensen AN, Dalsgaard A, Stockmarr A, Nielsen EM, Baggesen DL. Survival and transmission of salmonella enterica serovar typhimurium in an outdoor organic pig farming environment. Appl Environ Microbiol. 2006;72(3):183342 [cited $2020 \mathrm{Jul}$ 28] Available from: https://www.ncbi.n/m.nih.gov/pmc/a rticles/PMC1393233/.

46. Weaver T, Valcanis M, Mercoulia K, Sait M, Tuke J, Kiermeier A, et al. Longitudinal study of Salmonella 1,4,[5],12:i:- shedding in five Australian pig herds. Prev Vet Med. 2017;136:19-28. https://doi.org/10.1016/j.prevetmed.2 016.11 .010$.

47. Roesler U, Stief M, Leffler M, Truyen U, Lehmann J, Szabó I, et al. Persistenz, Ausscheidung und Wirksamkeit der attenuierten Salmonella Typhimurium Vakzine Salmoporc ${ }^{\oplus}$ bei Saugferkeln - Der Praktische Tierarzt - Vetline. Prakt
Tierarzt. 2010;91(1):59-65 [cited 2020 May 12]. Available from: https://vetline. de/salmonella-typhimurium-vakzine-salmoporc-saugferkel/150/3230/68900.

48. Mousing J, Jensen PT, Halgaard C, Bager F, Feld N, Nielsen B, et al. Nationwide Salmonella enterica surveillance and control in Danish slaughter swine herds. Prev Vet Med. 1997;29(4):247-61. https://doi.org/10.1016/S01675877(96)01082-3.

49. Merle R, Kösters S, May T, Portsch U, Blaha T, Kreienbrock L. Serological Salmonella monitoring in German pig herds: results of the years 2003-2008. Prev Vet Med. 2011;99(2-4):229-33. https://doi.org/10.1016/j.prevetmed.2 011.02.007.

50. van der Wolf PJ, Elbers AR, van der Heijden HM, van Schie FW, Hunneman WA, Tielen MJ. Salmonella seroprevalence at the population and herd level in pigs in the Netherlands. Vet Microbiol. 2001;80(2):171-84. https://doi. org/10.1016/S0378-1135(00)00387-4.

51. Hurd HS, McKean JD, Griffith RW, Wesley IV, Rostagno MH. Salmonella enterica infections in market swine with and without transport and holding. Appl Environ Microbiol. 2002;68(5):2376-81. https://doi.org/10.1128/AEM.68. 5.2376-2381.2002

52. McCarthy G, Lawlor PG, Gutierrez M, O'Sullivan L, Murphy A, Zhan X, et al. An assessment of Salmonella survival in pig manure and its separated solid and liquid fractions during storage. J Environ Sci Health Part B. 2015;50(2): 135-45. [cited 2020 Jun 16]. https://doi.org/10.1080/03601234.2015.975625.

53. Davies $\mathrm{RH}$, Wray C. Determination of an effective sampling regime to detect salmonella enteritidis in the environment of poultry units. Vet Microbiol. 1996;50(1):117-27 [cited 2020 Jun 23]. Available from: http://www. sciencedirect.com/science/article/pii/0378113596000314.

54. Robertson MH. Survival of S. typhimurium in floor dust - A possible reservoir of infection in institutions. Public Health. 1972;87(1):39-45 [cited 2020 Aug 31]. Available from: http://www.sciencedirect.com/science/article/ pii/S0033350672800349.

55. Swanenburg M, Berends BR, Urlings HA, Snijders JM, van Knapen F. Epidemiological investigations into the sources of Salmonella contamination of pork. Berl Munch Tierarztl Wochenschr. 2001;114(9-10): 356-9.

56. De Busser EV, De Zutter L, Dewulf J, Houf K, Maes D. Salmonella control in live pigs and at slaughter. Vet J Lond Engl 1997. 2013;196(1):20-7.

57. Walia K, Argüello H, Lynch H, Grant J, Leonard FC, Lawlor PG, et al. The efficacy of different cleaning and disinfection procedures to reduce Salmonella and Enterobacteriaceae in the lairage environment of a pig abattoir. Int J Food Microbiol. 2017;246:64-71. https://doi.org/10.1016/j. ijfoodmicro.2017.02.002

58. Mannion C, Egan J, Lynch BP, Fanning S, Leonard N. An investigation into the efficacy of washing trucks following the transportation of pigs--a salmonella perspective. Foodborne Pathog Dis. 2008;5(3):261-71. https://doi. org/10.1089/fpd.2007.0069.

59. Mannion C, Leonard FC, Lynch PB, Egan J. Efficacy of cleaning and disinfection on pig farms in Ireland. Vet Rec. 2007;161(11):371-5. https://doi. org/10.1136/vr.161.11.371.

60. Gosling RJ, Mawhinney I, Vaughan K, Davies RH, Smith RP. Efficacy of disinfectants and detergents intended for a pig farm environment where Salmonella is present. Vet Microbiol. 2017;204:46-53 [cited 2020 Jun 16]. Available from: http://www.sciencedirect.com/science/article/pii/S037811351 6308677.

61. Martelli F, Lambert M, Butt P, Cheney T, Tatone FA, Callaby R, et al. Evaluation of an enhanced cleaning and disinfection protocol in Salmonella contaminated pig holdings in the United Kingdom. PLoS One. 2017;12(6): e0178897. https://doi.org/10.1371/journal.pone.0178897.

62. Gotter V, Blaha T, Klein G. A case-control study on the occurrence of Salmonella spp. in the environment of pigs. Epidemiol Infect. 2012;140(1): 150-6 [cited 2020 Sep 21]. Available from: https://www.cambridge.org/core/ journals/epidemiology-and-infection/article/casecontrol-study-on-theoccurrence-of-salmonella-spp-in-the-environment-of-pigs/BB3C5A426F4 7DE8EFD1798993516A74D

63. Carrique-Mas JJ, Davies RH. Sampling and bacteriological detection of salmonella in poultry and poultry premises: a review. Rev Sci Tech. 2008; 27(3):665-77 [cited 2020 Jun 23]. Available from: https://doc.oie.int/dyn/ portal/index.seam?page $=$ alo\&alold $=30818$.

64. Gosling RJ, Mueller-Doblies D, Martelli F, Nunez-Garcia J, Kell N, Rabie A, et al. Observations on the distribution and persistence of monophasic Salmonella typhimurium on infected pig and cattle farms. Vet Microbiol. 2018;227:90-6. https://doi.org/10.1016/j.vetmic.2018.10.032. 
65. Snary EL, Munday DK, Arnold ME, Cook AJC. Zoonoses action plan Salmonella monitoring programme: an investigation of the sampling protocol. J Food Prot. 2010;73(3):488-94. https://doi.org/10.4315/0362-028X73.3.488.

66. Mainar-Jaime R, Casanova Higes A, Andrés-Barranco S, Vico JP. Looking for new approaches for the use of serology in the context of control programmes against pig salmonellosis. Zoonoses Public Health. 2017;8:65.

67. Nielsen B, Alban L, Stege H, Sørensen LL, Møgelmose V, Bagger J, et al. A new Salmonella surveillance and control programme in Danish pig herds and slaughterhouses. Berl Munch Tierarztl Wochenschr. 2001;114(9-10):323-6

68. Cargnel M, Maes D, Peeters L, Dispas M. Combining quantitative and qualitative approaches to determine viability of a potential Salmonella Typhimurium vaccination program in pigs in Belgium. Prev Vet Med. 2020 184:105132 [cited 2020 Nov 4]. Available from: http://www.sciencedirect. com/science/article/pii/S0167587720302713.

\section{Publisher's Note}

Springer Nature remains neutral with regard to jurisdictional claims in published maps and institutional affiliations.

Ready to submit your research? Choose BMC and benefit from:

- fast, convenient online submission

- thorough peer review by experienced researchers in your field

- rapid publication on acceptance

- support for research data, including large and complex data types

- gold Open Access which fosters wider collaboration and increased citations

- maximum visibility for your research: over $100 \mathrm{M}$ website views per year

At $\mathrm{BMC}$, research is always in progress.

Learn more biomedcentral.com/submissions 